\title{
Alterations in blood plasma and milk fatty acid profiles of lactating Holstein cows in response to ruminal infusion of a conjugated linoleic acid mixture
}

\author{
Juan J. Loor, Joseph H. HERBEIN* \\ Dairy Science Department, Virginia Tech, Blacksburg, VA, 24061-0315, USA
}

(Received 28 June 2001; accepted 5 October 2001)

\begin{abstract}
The production of intermediates during hydrogenation of conjugated linoleic acid (CLA) isomers was determined by infusing a CLA mixture (41\% cis 9 , trans $11-18: 2$ and $44 \%$ trans 10,cis 12-18:2) into the rumen of lactating cows. Four Holstein cows fed a basal diet were infused for $48 \mathrm{~h}$ with doses of $0,45,90$, or $180 \mathrm{~g} \mathrm{CLA} \cdot \mathrm{d}^{-1}$ into the rumen. Treatments were randomly assigned in a $4 \times 4$ Latin square with 4 -d experimental periods, and a 7-d transition between periods. Milk samples were obtained at -12 and $0 \mathrm{~h}$ before infusion, and at $12 \mathrm{~h}$ intervals from 0 to $96 \mathrm{~h}$ after infusion. Milk yield and DMI were not affected by treatment. Milk fat concentration was $12 \%$ lower, causing an $18 \%$ decrease in fat yield, when $180 \mathrm{~g} \mathrm{CLA} \cdot \mathrm{d}^{-1}$ was infused. Concentration of trans11-18:1 in blood plasma increased in proportion to CLA dose. Trans 10-18:1 concentration in blood plasma also increased, and was $240 \%$ greater when CLA was infused at $180 \mathrm{~g} \cdot \mathrm{d}^{-1}$. Trans 10, cis 12-18:2 was strictly a function of exogenous CLA input into the rumen, and ranged from 0.2 to $0.7 \mathrm{mg} \cdot \mathrm{g}^{-1}$ of total plasma fatty acids. Yields of saturated 6:0 to $16: 0 \mathrm{in}$ milk fat decreased by $87 \mathrm{~g} \cdot \mathrm{d}^{-1}$ when $180 \mathrm{~g} \mathrm{CLA} \cdot \mathrm{d}^{-1}$ was infused. Stearic acid concentration and yield increased by 25 and 6\%, but cis9-18:1 yield decreased, in response to increasing dose of CLA. Yields of trans11-18:1 and cis 9 ,trans 11-18:2 increased in proportion to CLA dose infused. Transfer rates of infused cis 9 ,trans 11-18:2 or trans 10,cis 12-18:2 into milk fat averaged 3\% at the highest dose of CLA infused. Milk fat yields of trans 10-18:1 and trans10,cis12-18:2 also increased in proportion to CLA input. Lower normalized ratios of $\operatorname{cis} 9-18: 1$ to 18:0 and cis9,trans11-18:2 to trans11-18:1 in milk fat when CLA was infused suggested CLA reduced desaturation in the mammary gland. Results provide additional evidence that enhanced flow of trans 10-18:1 or trans 10,cis12-18:2 from the rumen may decrease milk fat yield by reducing de novo synthesis and desaturation.
\end{abstract}

cis9,trans 11-18:2 / trans10,cis12-18:2 / trans10-18:1 / trans-vaccenic acid / milk fat

Résumé - Changements des profils des acides gras dans le plasma sanguin et le lait chez des vaches allaitantes Holstein en réponse à l'infusion ruminale d'un mélange d'acide linoléique conjugué. La production de composés intermédiaires pendant l'hydrogénation des isomères de l'acide linoléique conjugué (CLA) a été déterminée en infusant un mélange de CLA (41\% cis9,trans 11-18:2

* Correspondence and reprints

Tel.: 540231 4766; fax: 540231 5014; e-mail: herbeinj @ vt.edu 
et $44 \%$ trans 10 , cis $12-18: 2$ ) dans le rumen de vaches laitières. Des doses de $0,45,90$, ou $180 \mathrm{~g} \mathrm{CLA} \cdot \mathrm{j}^{-1}$ ont été infusées pendant $48 \mathrm{~h}$ dans le rumen de quatre vaches Holstein alimentées avec une ration complète. Les traitements ont été répartis de façon aléatoire selon un dispositif en carré latin $4 \times 4$ avec des périodes expérimentales de 4 jours et une transition de 7 jours entre chaque période. Des échantillons de lait ont été prélevés à -12 et $0 \mathrm{~h}$ avant l'infusion et à des intervalles de $12 \mathrm{~h}$ de 0 à $96 \mathrm{~h}$ après l'infusion. La production laitière et l'ingestion de matière sèche n'ont pas été affectées par le traitement. La teneur en matière grasse du lait a été inférieure de $12 \%$, provoquant une diminution de $18 \%$ de la production de matières grasses, lorsque $180 \mathrm{~g} \mathrm{CLA} \cdot \mathrm{j}^{-1}$ ont été infusés. La concentration du trans11-18:1 dans le plasma sanguin a augmenté proportionnellement à la dose de CLA. La concentration plasmatique du trans 10-18:1 a également augmenté et a été accrue de $240 \%$ lorsque le CLA a été infusé à $180 \mathrm{~g} \cdot \mathrm{j}^{-1}$. La concentration du trans 10, cis $12-18: 2$ a été strictement proportionnelle à l'apport de CLA exogène dans le rumen et a varié de 0,2 à $0,7 \mathrm{mg} \cdot \mathrm{g}^{-1} \mathrm{~d}$ 'acides gras totaux dans le plasma. Les productions des acides gras saturés de 6:0 à 16:0 dans la matière grasse du lait ont diminué de $87 \mathrm{~g} \cdot \mathrm{j}^{-1}$ lorsque $180 \mathrm{~g}$ de CLA $\cdot \mathrm{j}^{-1}$ ont été infusés. La concentration et la production d'acide stéarique ont été accrues de 25 et $6 \%$, alors que la production du cis9-18:1 a diminué, en réponse à l'augmentation des doses de CLA. Les productions du trans11-18:1 et du cis9,trans1118:2 ont augmenté proportionnellement à la dose de CLA infusée. Les taux de transfert dans la matière grasse du lait du cis9,trans 11-18:2 et du trans10,cis12-18:2 infusés ont été en moyenne de $3 \%$ à la dose la plus élevée de CLA infusée. Les productions du trans10-18:1 et du trans10,cis1218:2 ont augmenté dans les mêmes proportions que l'apport de CLA. La diminutions des rapports du cis9-18:1 au 18:0 et du cis9,trans11-18:2 au trans11-18:1 dans la matière grasse du lait lorsque le CLA est infusé suggère que le CLA a réduit le processus de désaturation dans la glande mammaire. Les résultats mettent en évidence que l'augmentation du flux du trans10-18:1 ou du trans10,cis12-18:2 à partir du rumen peut diminuer la production de matière grasse du lait en réduisant la synthèse de novo et la désaturation.

Cis9,trans11-18:2 / trans10,cis12-18:2 / trans10-18:1 / acide trans-vaccénique / matière grasse du lait

\section{INTRODUCTION}

The cis 9, trans 11 isomer of conjugated linoleic acid (CLA), accounts for nearly $90 \%$ of total CLA found in milk fat [18]. Cis 9 ,trans 11-18:2 results from isomerization, via cis 12 ,trans 11 -isomerase $[9,10]$, of dietary $18: 2 \mathrm{n} 6$ by rumen microorganisms during the first step of the biohydrogenation process [8]. Accumulation of trans11-18:1 and cis9,trans 11-18:2 in vitro, however, was lower when triglyceride-bound 18:2n6 was the substrate compared with the free fatty acid [15].

Diet affects the individual profiles of trans-18:1 or conjugated 18:2 isomers produced during fermentation. Feeding supplemental soybean oil resulted in greater duodenal flows of trans-18:1 with double bonds at positions 6 through 16 [3]. The output of cis9,trans11-18:2 in effluents from rumen fermenters fed fresh forage ranged from 9 to $23 \%$ of total conjugated-18:2 isomer output, and averaged $17 \%$ during digestion of a mixed diet plus supplemental 18:2n6 [4, 12]. Trans10,cis12-18:2 accounted for 7 or $16 \%$ of total conjugated isomer output when fresh forage or the mixed diet were the DM input [4, 12]. Outputs of cis9, cis 11-18:2,trans 11,trans 13-18:2, and a mixture of trans,trans-18:2 isomers were predominant regardless of diet fed $[4,12]$.

In terms of mammary lipid metabolism, identification of the precursors which give rise to the production of $18: 1$ and 18:2 isomers with a trans 10 double bond in the rumen is of interest because these isomers may depress milk fat synthesis [6, 19]. It is well established that production of trans 10-18:1 in the rumen is enhanced when high-grain diets containing supplemental oil are fed to dairy cows $[6,19]$. However, 
it is not clear if trans10,cis12-18:2 is a required precursor for the formation of trans 10-18:1. We showed [12] that production of trans 10-18:1 in rumen fermenters is directly proportional to cis $9-18: 1$ input from corn grain, but corn grain also contains substantial amounts of 18:2n6. One way to verify if trans10-18:1 can be formed during hydrogenation of trans10,cis12-18:2 in vivo, is to enhance the availability of the CLA in the rumen by infusing a mixture of CLA which contains substantial amounts of trans10,cis12-18:2. Our objective was to evaluate the extent of hydrogenation of cis 9,trans 11-18:2 and trans 10,cis12-18:2 in response to doses of a CLA mixture infused into the rumen.

\section{MATERIALS AND METHODS}

\subsection{Animals and diets}

Four early-lactation primiparous Holstein cows (between 48 and 60 d post-calving) with a rumen cannula were utilized in a $4 \times 4$ Latin square design with four 4 -d periods to evaluate responses to $0,45,90$, or $180 \mathrm{~g}$ CLA infused continuously into the rumen for 2-d. During infusion, cows were housed in a tie-stall barn and their basal diet was prepared and offered in equal amounts at 14.00 and $02.00 \mathrm{~h}$ daily. Feed refusals were removed daily at $12.00 \mathrm{~h}$ and $01.00 \mathrm{~h}$ and weighed. Daily feed allotment was calculated to allow 5 to $10 \%$ feed refusals. Cows were milked each day at 13.00 and $01.00 \mathrm{~h}$.

This basal diet was formulated using Dair4 [22] to meet or exceed nutrient requirements of cows producing $34 \mathrm{~kg}$ milk and consuming $19 \mathrm{~kg}$ of dry matter daily [14]. The concentrate portion of the diet was mixed in $500 \mathrm{~kg}$ batches, stored in sealed plastic containers, and removed as needed to mix with the forage on a daily basis (Tab. I). The experimental protocol was reviewed and approved by the Virginia Polytechnic Institute and State University Animal Care Committee.

\subsection{CLA infusion}

Conjugated linoleic acid (CLA-90, Natural Lipids, Norway) contained $90 \%$ nonesterified CLA, with cis9,trans 11-18:2 $\left(410 \mathrm{mg} \cdot \mathrm{g}^{-1}\right.$ total fatty acids) and trans 10 , cis $12-18: 2\left(440 \mathrm{mg} \cdot \mathrm{g}^{-1}\right)$ being the

Table I. Composition of the basal diet ${ }^{1}$.

\begin{tabular}{|c|c|}
\hline $\mathrm{g} \cdot \mathrm{k}$ & $\mathrm{g}^{-1} \mathrm{DM}$ \\
\hline \multicolumn{2}{|l|}{ Ingredient } \\
\hline Alfalfa silage & 315 \\
\hline Corn silage & 136 \\
\hline Orchardgrass hay & 70 \\
\hline Ground corn & 351 \\
\hline Soybean meal, $48 \%$ crude protein & 80 \\
\hline SoyPlus $^{2}$ & 34 \\
\hline Mineral/vitamin $\operatorname{mix}^{3}$ & 7 \\
\hline Limestone & 5 \\
\hline Dicalcium phosphate & 2 \\
\hline \multicolumn{2}{|l|}{ Chemical composition } \\
\hline $\mathrm{NDF}$ & 307 \\
\hline $\mathrm{ADF}$ & 195 \\
\hline Crude protein & 171 \\
\hline \multirow[t]{2}{*}{ Total fatty acids } & 30 \\
\hline & $\begin{array}{l}\mathrm{g} \cdot \mathrm{g}^{-1} \text { of } \\
\text { fatty acids }\end{array}$ \\
\hline $12: 0$ & 2 \\
\hline $14: 0$ & 1 \\
\hline $16: 0$ & 134 \\
\hline cis9-16:1 & 2 \\
\hline $18: 0$ & 34 \\
\hline cis $9-18: 1$ & 262 \\
\hline $18: 2 \mathrm{n} 6$ & 499 \\
\hline $18: 3 n 3$ & 66 \\
\hline
\end{tabular}

${ }^{1}$ Four samples (collected in each period) of forages and supplements were composited and analyzed in duplicate.

${ }^{2}$ SoyPlus ${ }^{\circledR}$ (West Central Cooperative, Ralston, IA, USA): Crude protein $=483 \mathrm{~g} \cdot \mathrm{kg}^{-1} \mathrm{DM}$, fatty acids = $48 \mathrm{~g} \cdot \mathrm{kg}^{-1} \mathrm{DM}$.

${ }^{3}$ Mineral/vitamin mix (Southern States Cooperative, Richmond, VA, USA): salt (38-48 $\left.\mathrm{g} \cdot \mathrm{kg}^{-1}\right), \mathrm{NaHCO}_{3}$ $\left(180 \mathrm{~g} \cdot \mathrm{kg}^{-1}\right), \mathrm{Ca}\left(145-174 \mathrm{~g} \cdot \mathrm{kg}^{-1}\right), \mathrm{P}\left(65 \mathrm{~g} \cdot \mathrm{kg}^{-1}\right)$, $\mathrm{Cl}\left(58 \mathrm{~g} \cdot \mathrm{kg}^{-1}\right), \mathrm{S}\left(32 \mathrm{~g} \cdot \mathrm{kg}^{-1}\right), \mathrm{Mg}\left(22 \mathrm{~g} \cdot \mathrm{kg}^{-1}\right), \mathrm{K}$ $\left(35 \mathrm{~g} \cdot \mathrm{kg}^{-1}\right), \mathrm{Mn}\left(1 \mathrm{~g} \cdot \mathrm{kg}^{-1}\right), \mathrm{Zn}\left(1 \mathrm{~g} \cdot \mathrm{kg}^{-1}\right), \mathrm{Fe}\left(0.3 \mathrm{~g} \cdot \mathrm{kg}^{-1}\right)$, $\mathrm{Cu}\left(0.1 \mathrm{~g} \cdot \mathrm{kg}^{-1}\right), \mathrm{I}\left(0.02 \mathrm{~g} \cdot \mathrm{kg}^{-1}\right), \mathrm{Co}\left(0.003 \mathrm{~g} \cdot \mathrm{kg}^{-1}\right), \mathrm{Se}$ $\left(0.005 \mathrm{~g} \cdot \mathrm{kg}^{-1}\right), \mathrm{F}\left(0.65 \mathrm{~g} \cdot \mathrm{kg}^{-1}\right)$, retinyl acetate $\left(0.36 \mathrm{~g} \cdot \mathrm{kg}^{-1}\right)$, cholecalciferol $\left(0.01 \mathrm{~g} \cdot \mathrm{kg}^{-1}\right)$, dl- $\alpha$-tocopherol acetate $\left(0.59 \mathrm{~g} \cdot \mathrm{kg}^{-1}\right)$. 
primary isomers. Concentrations of cis 9 , cis 11-18:2,trans 9 ,trans $11+$ trans 10 ,trans 12-18:2, and cis 10,cis12-18:2 averaged 18, 20 , and $12 \mathrm{mg} \cdot \mathrm{g}^{-1}$.

The CLA mixture $(0,45,90$, or $180 \mathrm{~g}$ CLA $\left.\cdot \mathrm{d}^{-1}\right)$ was emulsified in skim milk to ensure a uniform supply of CLA during the $48 \mathrm{~h}$ infusion. Emulsions were prepared the day prior to infusion by combining the desired amount of CLA with 0.23 g glycerol (Eastman Kodak Co., Rochester, NY, USA) $\cdot \mathrm{g}^{-1}$ CLA and $0.12 \mathrm{~g}$ soy lecithin powder (Refined, Alfa ${ }^{\circledR}$, Ward Hill, MA, USA) $\cdot \mathrm{g}^{-1}$ CLA in $972.5 \mathrm{~mL}$ skim milk at room temperature. The mixture was homogenized at $12000 \mathrm{rpm}$ for $2 \mathrm{~min}$ with a Polytron ${ }^{\circledR}$ PT 10/35 homogenizer (Brinkmann Instruments, Westbury, NY, USA), and checked for the presence of clumps before stirring at medium-to-high speed for $30 \mathrm{~min}$ at room temperature. Emulsions were dispensed into $1 \mathrm{~L} \mathrm{Viaflex}{ }^{\circledR}$ plastic bags (Baxter Corporation, Deerfield, IL, USA) and stored at $4{ }^{\circ} \mathrm{C}$ until infusion. Ruminal infusion of CLA began at $14.00 \mathrm{~h}$ in each period.

During infusion, bags containing CLA emulsions were attached to a flat platform on a wrist-action shaker (Burrell Corporation, Pittsburgh, PA, USA) set at low speed. Emulsions were infused via Tygon ${ }^{\circledR}$ tubing (1.6 mm i.d., $0.8 \mathrm{~mm}$ wall; Fisher Scientific Co., Pittsburgh, PA, USA) that passed through a Harvard Peristaltic pump (55-1762; Harvard Apparatus, South Natick, MA, USA). Flow from the pump was via Tygon ${ }^{\circledR}$ tubing (3.2 $\mathrm{mm}$ i.d., $1.6 \mathrm{~mm}$ wall) that passed through the rumen cannula and into the rumen. A perforated Nalgene ${ }^{\circledR}$ plastic bottle $(60 \mathrm{~mL})$ was attached to the end of the tubing. The tubing was primed with $15 \mathrm{~mL}$ infusate at the start of infusion, and flow rate was set at $41.7 \mathrm{~mL} \cdot \mathrm{h}^{-1}$.

\subsection{Sampling, measurements, and analysis}

Forages and concentrate were sampled during the last day of each experimental period. Samples were dried in a forced-air oven at $60^{\circ} \mathrm{C}$, then stored in sealed plastic containers. Equal amounts of samples from each period were combined to determine chemical composition. In preparation for analyses, dried forages and concentrate were ground first through a $2 \mathrm{~mm}$ screen (ThomasWiley Laboratory Mill), then through a $1 \mathrm{~mm}$ screen in a Cyclotec mill (Tecator 1093, Hoganas, Sweden). Forages and concentrates were analyzed for ADF and NDF [23] and total $\mathrm{N}$ [1].

Milk was collected in a stainless steel bucket, weighed, and thoroughly mixed prior to obtaining samples every $12 \mathrm{~h}$ from $-12 \mathrm{~h}$ before infusion through $96 \mathrm{~h}$ relative to the start of infusion. A $30 \mathrm{~mL}$ aliquot was collected in a $50 \mathrm{~mL}$ vial containing Bronopol (milk preservative; D \& F Control Systems, San Ramon, CA, USA) immediately after milking. Milk was analyzed for milk fat, protein, lactose, and solids-not-fat (SNF) by infrared analysis with a 4-channel spectrophotometer (Virginia Dairy Herd Improvement Association, VA, USA). An additional aliquot of milk without Bronopol also was collected, then frozen at $-20{ }^{\circ} \mathrm{C}$. Subsequently, samples were thawed at room temperature and centrifuged at $10000 \times g$ for $1 \mathrm{~h}$ to isolate milk fat.

Blood samples $(10 \mathrm{~mL})$ were obtained from the coccygeal artery immediately after the collection of milk samples. After collection, blood was transferred to tubes containing $286 \mathrm{IU}$ heparin in $100 \mu \mathrm{L}$ of sterile saline and centrifuged at $3000 \times g$ for $15 \mathrm{~min}$ for harvesting plasma.

Plasma lipids were extracted with chloroform/methanol (2:1, vol/vol). Fatty acids in forages, concentrate, milk fat, and blood plasma lipids were methylated by in situ transesterification with $0.5 \mathrm{~N}$ methanolic $\mathrm{NaOH}$ followed by $14 \%$ boron trifluoride in methanol as described by Park and Goins [17]. Undecenoate (Nu-Check Prep, Elysian, MN, USA) was used as the internal standard. Samples were injected by autosampler into a Hewlett-Packard 5890A gas 
chromatograph equipped with a flame ionization detector (Hewlett-Packard, Sunnyvale, CA, USA). Methyl esters of fatty acids were separated on a $100 \mathrm{~m} \times 0.25 \mathrm{~mm}$ i.d. fused silica capillary column (CP-Sil 88 Chrompack, Middelburg, The Netherlands). Pure methyl ester standards (Nu-Check Prep, Elysian, MN, USA; Supelco Inc., Bellefonte, PA, USA) were used to identify peaks, and determine correction factors for individual fatty acids.

For fatty acid analysis of milk fat, forage, and concentrate $(0.5 \mu \mathrm{L}$ methyl esters in hexane injected at a 35:1 split ratio) the injector temperature was maintained at $250{ }^{\circ} \mathrm{C}$ and the detector temperature was maintained at $255^{\circ} \mathrm{C}$. The initial oven temperature was $70^{\circ} \mathrm{C}$ (held for $1 \mathrm{~min}$ ) and increased $5^{\circ} \mathrm{C} \cdot \mathrm{min}^{-1}$ to $100{ }^{\circ} \mathrm{C}$ (held for $2 \mathrm{~min}$ ), $10^{\circ} \mathrm{C} \cdot \mathrm{min}^{-1}$ to $175^{\circ} \mathrm{C}$ (held for $40 \mathrm{~min})$, and then increased $5^{\circ} \mathrm{C} \cdot \mathrm{min}^{-1}$ to a final temperature of $225^{\circ} \mathrm{C}$ (held for $15 \mathrm{~min})$. Hydrogen was the carrier gas.

Analysis of blood plasma fatty acids required injection of $2 \mu \mathrm{L}$ methyl esters (splitless). The injector temperature was maintained at $150{ }^{\circ} \mathrm{C}$ and the detector temperature at $255^{\circ} \mathrm{C}$. The purge valve on the $\mathrm{GC}$ was closed for $1.5 \mathrm{~min}$ after sample injection. The initial column temperature was $40^{\circ} \mathrm{C}$ (held for $1.5 \mathrm{~min}$ ) and increased $40{ }^{\circ} \mathrm{C} \cdot \mathrm{min}^{-1}$ to $100{ }^{\circ} \mathrm{C}$ (held for $10 \mathrm{~min}$ ), $25^{\circ} \mathrm{C} \cdot \mathrm{min}^{-1}$ to $175^{\circ} \mathrm{C}$ (held for $70 \mathrm{~min}$ ), and then increased $10{ }^{\circ} \mathrm{C} \cdot \mathrm{min}^{-1}$ to a final temperature of $220^{\circ} \mathrm{C}$ (held for $20 \mathrm{~min}$ ). Ultra pure helium was the carrier gas.

\subsection{Statistical analysis}

Data for dry matter and fatty acid intake, milk production and composition, plasma fatty acid profiles, milk fatty acid yields, and normalized ratios of milk fatty acids are reported as Least squares means \pm SEM. All data, except plasma fatty acid profiles, were analyzed as a $4 \times 4$ Latin square with repeated measures using the MIXED procedure of SAS [21]. Observations obtained at -12 and $0 \mathrm{~h}$ were averaged and served as a covariate for observations at 12, 24, 36, $48,60,72,84$, or $96 \mathrm{~h}$. Main effects in the model included covariate adjustment, cow, period, CLA dose, time, time by CLA dose interaction, and residual error. For plasma fatty acid profiles, main effects in the model included cow, period, CLA dose, and residual error. Linear and quadratic contrasts were used to determine differences due to CLA infusion. Overall differences between treatment means were considered to be significant when $P \leq 0.05$. However, all $P$-values are presented in tables.

\section{RESULTS}

\subsection{Diet composition}

Total fatty acid content of the basal diet was $30 \mathrm{~g} \cdot \mathrm{kg}^{-1}$ (Tab. I). Linoleic acid accounted for $500 \mathrm{mg} \cdot \mathrm{g}^{-1}$ of total fatty acids, and cis $9-18: 1$ and $18: 3 \mathrm{n} 3$ for 260 or $70 \mathrm{mg} \cdot \mathrm{g}^{-1}$ of total fatty acids. The primary sources of fatty acids were SoyPlus ${ }^{\circledR}$ and ground corn, which provided the majority of supplemental 18:2n6. Forages contributed primarily $18: 3 \mathrm{n} 3$.

\subsection{Fatty acid intake, dry matter intake, and milk production}

Estimated intake of total fatty acids increased in proportion with CLA dose due to the combination of the amounts of CLA infused (Tab. II) and variations in dry matter intake (DMI) (Tab. III). Daily DMI and milk yields were not affected by dose of CLA, and averaged 19 or $31 \mathrm{~kg} \cdot \mathrm{d}^{-1}$ (Tab. III). Because of numerically lower milk yield as the dose of CLA infusion increased, yields of protein, lactose, and SNF in milk also decreased. Milk fat percentage and yield decreased by 13 and $16 \%$ due primarily to CLA infusion at $180 \mathrm{~g} \cdot \mathrm{d}^{-1}$. At this rate of CLA infusion, concentration of milk fat (Fig. 1A) decreased markedly from 
Table II. Estimated daily fatty acid intake by cows infused continuously into the rumen for $2 \mathrm{~d}$ with $0,45,90$, or $180 \mathrm{~g} \cdot \mathrm{d}^{-1}$ of a conjugated linoleic acid (CLA) mixture ${ }^{1}$.

\begin{tabular}{|c|c|c|c|c|c|c|c|c|}
\hline & \multicolumn{4}{|c|}{$\operatorname{CLA}\left(\mathrm{g} \cdot \mathrm{d}^{-1}\right)$} & \multirow[b]{2}{*}{ SEM } & \multicolumn{3}{|c|}{ Effect $^{2}$} \\
\hline & 0 & 45 & 90 & 180 & & CLA & $\mathrm{L}$ & Q \\
\hline Fatty acid & \multicolumn{4}{|c|}{$\mathrm{g} \cdot \mathrm{d}^{-1}$} & & & & \\
\hline $14: 0$ & 0.8 & 0.8 & 0.8 & 0.8 & 0.04 & 0.33 & 0.67 & 0.54 \\
\hline $16: 0$ & 73.6 & 78.7 & 74.4 & 73.6 & 3.4 & 0.33 & 0.67 & 0.55 \\
\hline cis9-16:1 & 1.1 & 1.2 & 1.1 & 1.1 & 0.03 & 0.33 & 0.67 & 0.56 \\
\hline 18:0 & 18.0 & 23.1 & 26.2 & 23.8 & 0.8 & 0.01 & 0.01 & 0.29 \\
\hline cis9-18:1 & 137.3 & 146.2 & 138.6 & 137.3 & 7.0 & 0.39 & 0.89 & 0.48 \\
\hline \multicolumn{9}{|l|}{$18: 2$ isomers } \\
\hline cis 9, cis 12 & 264.4 & 282.8 & 267.1 & 264.6 & 13.8 & 0.32 & 0.66 & 0.44 \\
\hline cis 9, trans 11 & 0.0 & 20.4 & 40.8 & 81.5 & $\ldots$ & $\ldots$ & $\ldots$ & $\ldots$ \\
\hline $\operatorname{trans} 10$, cis 12 & 0.0 & 21.8 & 43.7 & 87.5 & $\ldots$ & $\ldots$ & $\ldots$ & $\ldots$ \\
\hline cis 9, cis 11 & 0.0 & 0.8 & 1.5 & 3.0 & $\ldots$ & $\ldots$ & $\ldots$ & $\ldots$ \\
\hline cis $10, c i s 12$ & 0.0 & 0.5 & 1.0 & 2.0 & $\ldots$ & $\ldots$ & $\ldots$ & $\ldots$ \\
\hline 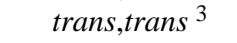 & 0.0 & 0.9 & 1.9 & 3.8 & $\ldots$ & $\ldots$ & $\ldots$ & $\ldots$ \\
\hline other & 0.0 & 0.6 & 1.1 & 2.2 & $\ldots$ & $\ldots$ & $\cdots$ & $\ldots$ \\
\hline $18: 3 n 3$ & 19.8 & 20.5 & 19.4 & 19.5 & 1.0 & 0.33 & 0.67 & 0.45 \\
\hline Total & 558.8 & 605.1 & 599.2 & 651.2 & 19.1 & 0.01 & 0.01 & 0.82 \\
\hline
\end{tabular}

${ }^{1}$ Values are the average of means obtained during CLA infusion, and include the daily amount of CLA isomers infused.

2 Overall effect due to CLA, and linear (L) or quadratic (Q) effects of CLA dose.

${ }^{3}$ trans 9, trans $11+$ trans 10 , trans 12 .

36 through $84 \mathrm{~h}$, and remained below preinfusion levels by $96 \mathrm{~h}$.

\subsection{Blood plasma fatty acid profiles}

Overall, total plasma fatty acid concentrations did not differ due to CLA dose and averaged $1132 \mu \mathrm{g} \cdot \mathrm{mL}^{-1}$ at the end of the 48-h ruminal infusion (Tab. IV). Among 18:1 isomers derived from hydrogenation of exogenous cis 9 ,trans 11-18:2 and trans10,cis12-18:2, concentrations of trans 10-18:1 and trans11-18:1 increased in proportion to dose of CLA infused. Compared with basal $\left(0 \mathrm{~g} \mathrm{CLA} \cdot \mathrm{d}^{-1}\right)$, however, the extent of the increase was greater for trans 10-18:1 (+225\%) than trans 11-18:1 $(+68 \%)$ when $180 \mathrm{~g} \mathrm{CLA} \cdot \mathrm{d}^{-1}$ were infused. Concentrations of trans10,cis12-18:2 also were proportional to CLA dose, and averaged $0,0.2,0.5$, or $0.7 \mu \mathrm{g} \cdot \mathrm{mL}^{-1}$ when 0,22 , 44 , or $88 \mathrm{~g}$ trans 10 , cis $12-\mathrm{CLA} \cdot \mathrm{d}^{-1}$ were infused. Although not statistically significant, the concentration of cis 9 ,trans 11-18:2 was $33 \%\left(0.5 \mu \mathrm{g} \cdot \mathrm{mL}^{-1}\right)$ greater due to infusion of $180 \mathrm{~g} \mathrm{CLA} \cdot \mathrm{d}^{-1}$ compared with basal levels.

\subsection{Milk fatty acid yields}

Total milk fatty acid yield during the $96 \mathrm{~h}$ period relative to basal levels decreased $13 \%$ when the $180 \mathrm{~g} \mathrm{CLA} \cdot \mathrm{d}^{-1}$ dose was infused for $48 \mathrm{~h}$ (Tab. V). The decrease was primarily due to a $22 \%$ reduction in yields of saturated fatty acids with 6 to 16 carbons. Concentration of these fatty acids in response to $180 \mathrm{~g} \mathrm{CLA} \cdot \mathrm{d}^{-1}$ infused decreased linearly 
Table III. Dry matter intake (DMI) and milk production, composition, and component yields by cows infused continuously into the rumen for $2 \mathrm{~d}$ with $0,45,90$, or $180 \mathrm{~g} \cdot \mathrm{d}^{-1}$ of a conjugated linoleic acid (CLA) mixture ${ }^{1}$.

\begin{tabular}{|c|c|c|c|c|c|c|c|c|}
\hline & \multicolumn{4}{|c|}{ CLA $\left(g \cdot d^{-1}\right)$} & \multirow[b]{2}{*}{ SEM } & \multicolumn{3}{|c|}{ Effect $^{2}$} \\
\hline & 0 & 45 & 90 & 180 & & CLA & $\mathrm{L}$ & $\mathrm{Q}$ \\
\hline Item & \multicolumn{4}{|c|}{$\mathrm{kg} \cdot \mathrm{d}^{-1}$} & & & & \\
\hline DMI & 18.6 & 19.4 & 18.4 & 18.4 & 0.8 & 0.33 & 0.67 & 0.45 \\
\hline Milk yield & 32.0 & 31.4 & 31.6 & 30.7 & 0.9 & 0.08 & 0.06 & 0.54 \\
\hline Composition & \multicolumn{4}{|c|}{$\%$} & & & & \\
\hline Fat & 3.53 & 3.61 & 3.57 & 3.11 & 0.10 & 0.01 & 0.02 & 0.01 \\
\hline Protein & 2.82 & 2.80 & 2.83 & 2.80 & 0.05 & 0.44 & 0.50 & 0.56 \\
\hline Lactose & 4.68 & 4.65 & 4.66 & 4.64 & 0.04 & 0.03 & 0.01 & 0.85 \\
\hline SNF & 8.25 & 8.19 & 8.24 & 8.19 & 0.07 & 0.07 & 0.03 & 0.90 \\
\hline Yield & \multicolumn{4}{|c|}{$\mathrm{kg} \cdot \mathrm{d}^{-1}$} & & & & \\
\hline Fat & 1.14 & 1.12 & 1.14 & 0.95 & 0.04 & 0.01 & 0.01 & 0.01 \\
\hline Protein & 0.90 & 0.88 & 0.90 & 0.84 & 0.02 & 0.01 & 0.01 & 0.13 \\
\hline Lactose & 1.50 & 1.46 & 1.48 & 1.41 & 0.04 & 0.02 & 0.01 & 0.31 \\
\hline SNF & 2.64 & 2.58 & 2.62 & 2.46 & 0.05 & 0.02 & 0.01 & 0.24 \\
\hline
\end{tabular}

${ }^{1}$ Values are the average of means obtained every $12 \mathrm{~h}$ from 12 through $96 \mathrm{~h}$ after the start of infusions.

2 Overall effect due to CLA, and linear (L) or quadratic (Q) effects of CLA dose.

Figure 1. Milk fat percentage (A) and concentration (B) of saturated 6:0 to 16:0 fatty acids in milk fat from cows infused continuously into the rumen for $2 \mathrm{~d}$ with 0,45 , 90 , or $180 \mathrm{~g} \cdot \mathrm{d}^{-1}$ of a conjugated linoleic acid (CLA) mixture. Values are means plus pooled SEM for four cows at each $12 \mathrm{~h}$ milking interval. Infusion of $180 \mathrm{~g} \mathrm{CLA} \cdot \mathrm{d}^{-1}$ decreased $(P<0.05)$ milk fat percentage and concentrations of saturated 6:0 to $16: 0$ fatty acids in milk fat.
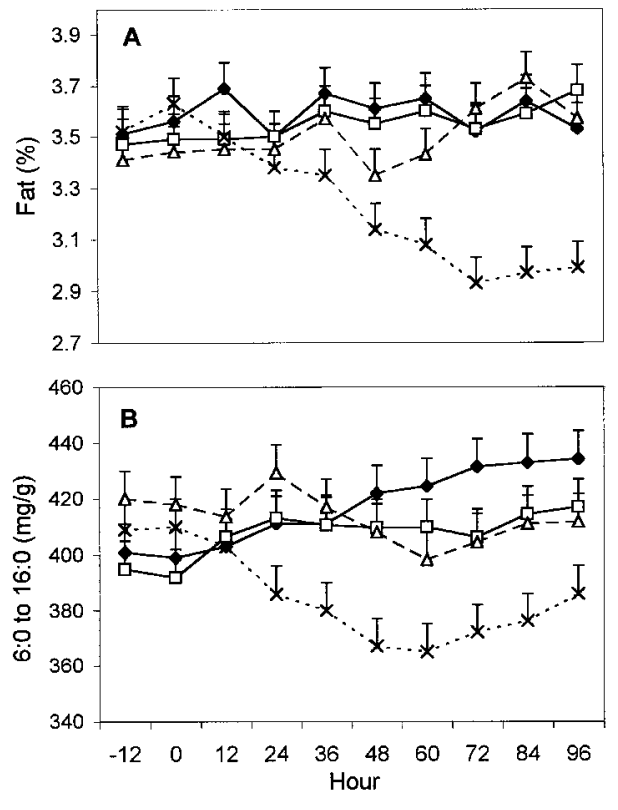

$\longrightarrow 0 \rightarrow-45-\Delta-90 \cdots * \cdots 180$ 
from 12 through $60 \mathrm{~h}$ (Fig. 1B) and, similar to milk fat percentage, did not return to preinfusion levels by $96 \mathrm{~h}$. The yield of 18:0, however, was greater due to infusion of
CLA. A marked increase in concentration of 18:0 (Fig. 2A), was observed from 12 to $60 \mathrm{~h}$ of $180 \mathrm{~g} \mathrm{CLA} \cdot \mathrm{d}^{-1}$ infusion. In contrast, yield of cis9-18:1 (derived in part from 18:0

Table IV. Fatty acid concentrations in blood plasma from cows infused continuously into the rumen for $2 \mathrm{~d}$ with $0,45,90$, or $180 \mathrm{~g} \cdot \mathrm{d}^{-1}$ of a conjugated linoleic acid (CLA) mixture ${ }^{1}$.

\begin{tabular}{|c|c|c|c|c|c|c|c|c|}
\hline & & CLA & $\left(g \cdot d^{-1}\right)$ & & & & Effect $^{2}$ & \\
\hline & 0 & 45 & 90 & 180 & SEM & CLA & $\mathrm{L}$ & Q \\
\hline Fatty acid & & & $\cdot \mathrm{mL}^{-1}$ & & & & & \\
\hline $14: 0$ & 4.6 & 4.1 & 5.3 & 4.1 & 0.4 & 0.26 & 0.25 & 0.57 \\
\hline cis9-14:1 & 2.1 & 1.1 & 2.6 & 1.6 & 1.3 & 0.66 & 0.29 & 0.86 \\
\hline $16: 0$ & 115 & 111 & 134 & 100 & 17 & 0.40 & 0.25 & 0.74 \\
\hline cis9-16:1 & 16 & 12 & 17 & 12 & 2 & 0.22 & 0.17 & 0.85 \\
\hline $\operatorname{trans} 9-16: 1$ & 2.2 & 1.4 & 2.4 & 1.9 & 0.4 & 0.37 & 0.62 & 0.70 \\
\hline 18:0 & 132 & 120 & 151 & 117 & 18 & 0.27 & 0.43 & 0.39 \\
\hline Cis 18:1 & & & & & & & & \\
\hline 9 & 101 & 91 & 112 & 91 & 12 & 0.55 & 0.53 & 0.63 \\
\hline 11 & 4.5 & 4.0 & 5.0 & 3.8 & 0.5 & 0.26 & 0.28 & 0.45 \\
\hline 12 & 4.1 & 3.3 & 4.9 & 3.9 & 0.5 & 0.13 & 0.68 & 0.82 \\
\hline 13 & 0.9 & 0.6 & 1.1 & 0.7 & 0.1 & 0.01 & 0.05 & 0.16 \\
\hline 15 & 0.8 & 0.8 & 1.1 & 0.8 & 0.1 & 0.03 & 0.52 & 0.09 \\
\hline Trans 18:1 & & & & & & & & \\
\hline $6,7,8$ & 0.3 & 0.3 & 0.4 & 0.6 & 0.2 & 0.49 & 0.22 & 0.60 \\
\hline 9 & 0.3 & 0.3 & 0.4 & 0.4 & 0.1 & 0.48 & 0.35 & 0.77 \\
\hline 10 & 0.4 & 0.6 & 0.9 & 1.3 & 0.2 & 0.02 & 0.01 & 0.58 \\
\hline 11 & 3.1 & 3.2 & 4.4 & 5.2 & 0.4 & 0.04 & 0.02 & 0.46 \\
\hline 12 & 1.1 & 1.0 & 1.4 & 1.2 & 0.2 & 0.37 & 0.85 & 0.70 \\
\hline 13,14 & 1.5 & 1.4 & 2.1 & 1.8 & 0.2 & 0.15 & 0.29 & 0.68 \\
\hline 16 & 0.7 & 0.7 & 1.1 & 0.8 & 0.2 & 0.05 & 0.25 & 0.16 \\
\hline Isolated 18:2 & & & & & & & & \\
\hline cis 9, cis 12 & 652 & 540 & 686 & 543 & 90.1 & 0.32 & 0.26 & 0.81 \\
\hline trans 9, trans 12 & 0.2 & 0.1 & 0.2 & 0.2 & 0.1 & 0.40 & 0.70 & 0.47 \\
\hline trans 9, cis 12 & 1.5 & 1.8 & 1.3 & 1.7 & 0.3 & 0.59 & 0.59 & 0.79 \\
\hline trans 11, cis 15 & 1.5 & 1.0 & 1.5 & 0.9 & 0.1 & 0.01 & 0.01 & 0.36 \\
\hline Conjugated 18:2 & & & & & & & & \\
\hline cis 9, trans 11 & 1.5 & 1.2 & 2.0 & 2.0 & 0.3 & 0.23 & 0.25 & 0.61 \\
\hline $\operatorname{trans} 10$, cis 12 & 0.0 & 0.2 & 0.5 & 0.7 & 0.02 & 0.01 & 0.01 & 0.92 \\
\hline $18: 3 \mathrm{n} 3$ & 59 & 48 & 62 & 47 & 7.3 & 0.31 & 0.23 & 0.77 \\
\hline $20: 3 n 3$ & 18 & 15 & 21 & 15 & 4.7 & 0.17 & 0.31 & 0.49 \\
\hline 20:4n6 & 32 & 26 & 35 & 26 & 7.0 & 0.35 & 0.31 & 0.79 \\
\hline $20: 5 n 3$ & 16 & 13 & 18 & 14 & 4.3 & 0.38 & 0.50 & 0.98 \\
\hline Total & 1205 & 1016 & 1287 & 1021 & 164 & 0.32 & 0.30 & 0.75 \\
\hline
\end{tabular}

${ }^{1}$ Values are the average of means obtained at the end of $48 \mathrm{~h}$ of infusion.

${ }^{2}$ Overall effect due to CLA, and linear (L) or quadratic (Q) effects of CLA dose. 
Table V. Milk fatty acid yields by cows infused continuously into the rumen for $2 \mathrm{~d}$ with $0,45,90$, or $180 \mathrm{~g} \cdot \mathrm{d}^{-1}$ of a conjugated linoleic acid (CLA) mixture ${ }^{1}$.

\begin{tabular}{|c|c|c|c|c|c|c|c|c|}
\hline & & CLA & $\left(g \cdot d^{-1}\right)$ & & & & Effect $^{2}$ & \\
\hline & 0 & 45 & 90 & 180 & SEM & CLA & $\mathrm{L}$ & Q \\
\hline Fatty acid & & & $d^{-1}$ & & & & & \\
\hline $4: 0$ & 48.2 & 49.4 & 46.8 & 43.0 & 2.0 & 0.01 & 0.01 & 0.02 \\
\hline $6: 0$ & 23.6 & 23.4 & 23.6 & 19.0 & 0.6 & 0.01 & 0.01 & 0.01 \\
\hline 8:0 & 11.6 & 11.2 & 11.6 & 8.6 & 0.2 & 0.01 & 0.01 & 0.01 \\
\hline 10:0 & 21.6 & 20.0 & 21.4 & 15.0 & 0.6 & 0.01 & 0.01 & 0.01 \\
\hline 12:0 & 22.6 & 21.0 & 22.4 & 16.2 & 0.6 & 0.01 & 0.01 & 0.01 \\
\hline $14: 0$ & 86.6 & 83.0 & 82.8 & 65.6 & 1.1 & 0.01 & 0.01 & 0.01 \\
\hline cis9-14:1 & 7.2 & 6.4 & 6.6 & 5.2 & 0.2 & 0.01 & 0.01 & 0.04 \\
\hline $16: 0$ & 234.2 & 228.8 & 222.4 & 185.6 & 5.2 & 0.01 & 0.01 & 0.01 \\
\hline $6: 0$ to $16: 0$ & 399.4 & 385.2 & 384.6 & 312.4 & 8.4 & 0.01 & 0.01 & 0.01 \\
\hline cis9-16:1 & 18.4 & 18.2 & 17.4 & 14.4 & 0.5 & 0.01 & 0.01 & 0.01 \\
\hline trans $9-16: 1$ & 4.2 & 4.4 & 4.2 & 3.8 & 0.2 & 0.03 & 0.07 & 0.02 \\
\hline 18:0 & 113.6 & 127.8 & 120.6 & 120.6 & 4.1 & 0.01 & 0.04 & 0.01 \\
\hline Cis 18:1 & & & & & & & & \\
\hline 9 & 266.2 & 276.2 & 271.2 & 243.4 & 6.2 & 0.01 & 0.01 & 0.01 \\
\hline 11 & 10.0 & 10.2 & 10.0 & 8.8 & 0.3 & 0.01 & 0.01 & 0.01 \\
\hline 12 & 6.6 & 6.2 & 6.2 & 6.2 & 0.2 & 0.67 & 0.28 & 0.61 \\
\hline 13 & 4.2 & 4.2 & 3.8 & 3.4 & 0.3 & 0.17 & 0.07 & 0.43 \\
\hline 15 & 2.2 & 2.4 & 2.2 & 2.2 & 0.2 & 0.65 & 0.52 & 0.72 \\
\hline Trans 18:1 & & & & & & & & \\
\hline $6,7,8$ & 2.2 & 2.4 & 2.4 & 2.4 & 0.04 & 0.01 & 0.01 & 0.14 \\
\hline 9 & 1.6 & 1.8 & 1.8 & 1.8 & 0.05 & 0.05 & 0.01 & 0.37 \\
\hline 10 & 2.2 & 2.6 & 2.8 & 3.8 & 0.1 & 0.01 & 0.01 & 0.01 \\
\hline 11 & 8.2 & 8.6 & 8.8 & 10.2 & 0.1 & 0.01 & 0.01 & 0.07 \\
\hline 12 & 2.0 & 2.2 & 2.4 & 2.8 & 0.04 & 0.01 & 0.01 & 0.26 \\
\hline 13,14 & 4.0 & 4.8 & 5.4 & 5.6 & 0.1 & 0.01 & 0.01 & 0.27 \\
\hline 16 & 2.8 & 2.8 & 3.0 & 3.0 & 0.1 & 0.21 & 0.08 & 0.70 \\
\hline Isolated 18:2 & & & & & & & & \\
\hline cis 9, cis 12 & 25.8 & 26.8 & 25.2 & 23.0 & 0.3 & 0.01 & 0.01 & 0.01 \\
\hline $\operatorname{trans} 9, \operatorname{trans} 12$ & 0.2 & 0.2 & 0.2 & 0.2 & 0.02 & 0.16 & 0.34 & 0.79 \\
\hline trans $11, \operatorname{cis} 15$ & 1.2 & 1.2 & 1.2 & 0.8 & 0.02 & 0.01 & 0.13 & 0.02 \\
\hline Conjugated 18:2 & & & & & & & & \\
\hline cis 9, trans 11 & 6.2 & 6.0 & 6.4 & 6.6 & 0.1 & 0.04 & 0.04 & 0.31 \\
\hline $\operatorname{trans} 10, \operatorname{cis} 12$ & 0.0 & 0.2 & 0.6 & 1.0 & 0.02 & 0.01 & 0.01 & 0.13 \\
\hline $18: 3 n 3$ & 4.4 & 4.6 & 4.4 & 3.8 & 0.04 & 0.01 & 0.01 & 0.01 \\
\hline $20: 3 n 3$ & 0.6 & 0.8 & 0.8 & 0.6 & 0.03 & 0.28 & 0.69 & 0.06 \\
\hline $20: 4 n 6$ & 1.4 & 1.4 & 1.6 & 1.2 & 0.03 & 0.04 & 0.38 & 0.01 \\
\hline $20: 5 n 3$ & 0.1 & 0.1 & 0.1 & 0.1 & 0.02 & 0.16 & 0.03 & 0.97 \\
\hline Total & 947.0 & 964.4 & 940.0 & 825.0 & 15.0 & 0.01 & 0.01 & 0.01 \\
\hline
\end{tabular}

${ }^{1}$ Values are the average of means obtained every $12 \mathrm{~h}$ from 12 through $96 \mathrm{~h}$ after the start of infusions.

${ }^{2}$ Overall effect due to CLA, and linear (L) or quadratic (Q) effects of CLA dose. 
desaturation) decreased when the dose of CLA was $180 \mathrm{~g}$. Compared with the control infusion, yields of cis9,trans 11-18:2 were only $6 \%$ greater when 90 or 180 g CLA were infused. Supplemental CLA was the primary source of trans10,cis12-18:2 in the rumen,
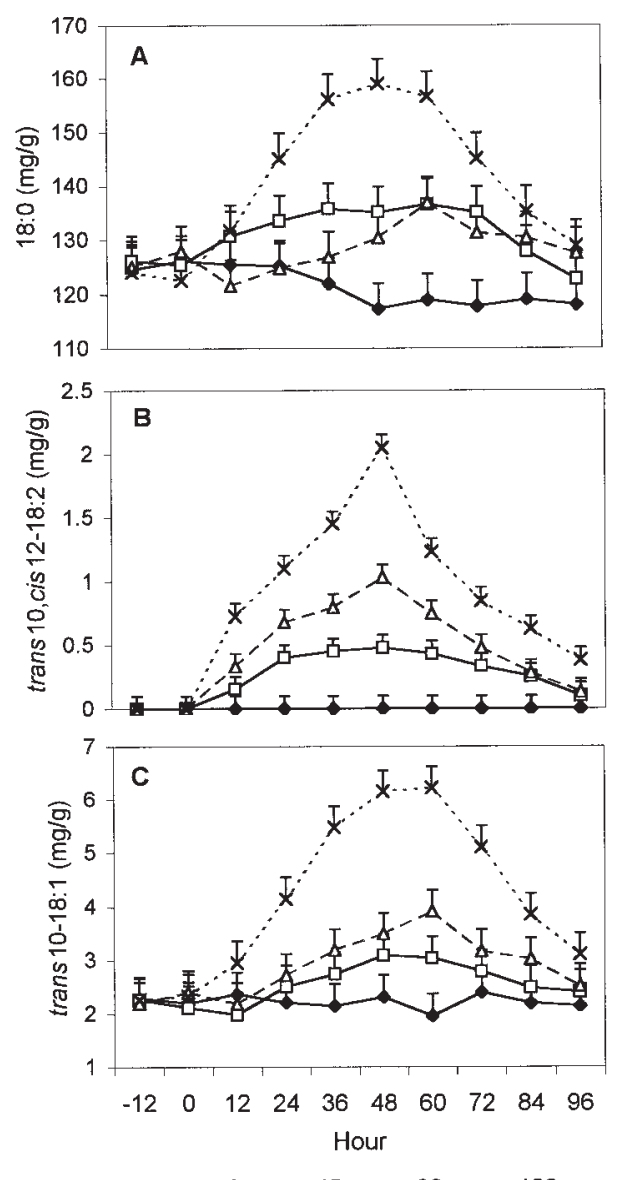

Figure 2. Concentrations of 18:0 (A), trans10,cis 12-18:2 (B), and trans10-18:1 (C) in milk fat from cows infused continuously into the rumen for $2 \mathrm{~d}$ with $0,45,90$, or $180 \mathrm{~g} \cdot \mathrm{d}^{-1}$ of a conjugated linoleic acid (CLA) mixture. Values are means plus pooled SEM for four cows at each $12 \mathrm{~h}$ milking interval. Incremental infusion of CLA resulted in a linear increase $(P<0.05)$ in concentrations of 18:0, trans 10 , cis $12-18: 2$, and trans 10-18:1 in milk fat. and resulted in yields of $0.2,0.6$, and $1 \mathrm{~g} \cdot \mathrm{d}^{-1}$ when 22,44 , or $88 \mathrm{~g}$ trans 10 , cis 12-CLA. $\mathrm{d}^{-1}$, respectively, were infused. Greater yields of this CLA corresponded with its gradual incorporation into milk fat. Concentrations of trans10,cis12-18:2 (Fig. 2B) increased from non-detectable levels at -12 or $0 \mathrm{~h}$ before infusion to $0.5,1.1$, or $2.2 \mathrm{mg} \cdot \mathrm{g}^{-1}$ at $60 \mathrm{~h}$ of due to infusion of 22,44 , or $88 \mathrm{~g}$ trans 10 , cis $12-18: 2 \cdot \mathrm{d}^{-1}$. All doses of CLA increased the yields of most trans-18:1 isomers compared with the control infusion without CLA. Trans10-18:1 concentration (Fig. 2C), in particular, increased gradually from 12 through $60 \mathrm{~h}$ of CLA infusion, but the response was more pronounced due to 180 g CLA.

\subsection{Normalized ratios of milk fatty acids}

Normalized ratios $\left(\mathrm{mg} \cdot \mathrm{g}^{-1}\right.$ product/ $\left[\mathrm{mg} \cdot \mathrm{g}^{-1}\right.$ substrate $+\mathrm{mg} \cdot \mathrm{g}^{-1}$ product]) [16] were estimated to assess the relative extent of desaturation of specific fatty acids during milk fat synthesis in response to elevated amounts of trans 10, cis $12-18: 2$ or cis 9 ,trans 11-18:2 [5, 12]. The ratios of cis $9-14: 1$ to 14:0 (mg.g ${ }^{-1}$ cis $9-14: 1 /\left[\mathrm{mg} \cdot \mathrm{g}^{-1} 14: 0+\mathrm{mg} \cdot \mathrm{g}^{-1}\right.$ cis9-14:1]), cis9-18:1 to 18:0, and cis9,trans 11-18:2 to trans11-18:1 decreased due to CLA infusion, primarily at the $180 \mathrm{~g}$ dose (Tab. VI).

\section{DISCUSSION}

Our experiment evaluated the quantitative significance of ruminal availability of cis9,trans11-18:2 and trans10,cis12-18:2 on their secretion in milk fat. Plasma fatty acid profiles and milk fatty acid yields were used to assess changes in the production of hydrogenation intermediates. Milk fatty acid data also provided the means to evaluate apparent changes in lipogenesis and desaturation in the mammary gland due to exogenous CLA. Daily DMI or milk yield were not affected by CLA dose. 
Table VI. Normalized ratios ${ }^{1}$ of fatty acids in milk fat from cows infused continuously into the rumen for $2 \mathrm{~d}$ with $0,45,90$, or $180 \mathrm{~g} \cdot \mathrm{d}^{-1}$ of a conjugated linoleic acid (CLA) mixture 2 .

\begin{tabular}{|c|c|c|c|c|c|c|c|c|}
\hline & \multicolumn{4}{|c|}{$\operatorname{CLA}\left(\mathrm{g} \cdot \mathrm{d}^{-1}\right)$} & \multirow[b]{2}{*}{ SEM } & \multicolumn{3}{|c|}{ Effect $^{3}$} \\
\hline & 0 & 45 & 90 & 180 & & CLA & $\mathrm{L}$ & Q \\
\hline \multicolumn{9}{|l|}{ Ratio } \\
\hline $14: 1 \Rightarrow 14: 0$ & 0.079 & 0.072 & 0.074 & 0.073 & 0.002 & 0.04 & 0.03 & 0.12 \\
\hline $16: 1 \Rightarrow 16: 0$ & 0.072 & 0.072 & 0.072 & 0.072 & 0.004 & 0.96 & 0.74 & 0.79 \\
\hline $18: 1 \Rightarrow 18: 0$ & 0.70 & 0.68 & 0.69 & 0.66 & 0.003 & 0.01 & 0.01 & 0.90 \\
\hline $\begin{array}{l}\text { cis } 9, \text { trans } 11-18: 2 \Rightarrow \\
\text { trans } 11-18: 1\end{array}$ & 0.43 & 0.41 & 0.42 & 0.39 & 0.004 & 0.01 & 0.01 & 0.94 \\
\hline $20: 4 \mathrm{n} 6 \Rightarrow 18: 2 \mathrm{n} 6$ & 0.049 & 0.053 & 0.058 & 0.049 & 0.003 & 0.11 & 0.83 & 0.03 \\
\hline $20: 5 \mathrm{n} 3 \Rightarrow 18: 3 \mathrm{n} 3$ & 0.059 & 0.054 & 0.054 & 0.046 & 0.004 & 0.38 & 0.10 & 0.79 \\
\hline
\end{tabular}

${ }^{1}$ Normalized ratio $=\mathrm{mg} \cdot \mathrm{g}^{-1}$ product $/\left[\mathrm{mg} \cdot \mathrm{g}^{-1}\right.$ substrate $+\mathrm{mg} \cdot \mathrm{g}^{-1}$ product $]$.

${ }^{2}$ Values are the average of means obtained every $12 \mathrm{~h}$ from 12 through $96 \mathrm{~h}$ after the start of infusions.

${ }^{3}$ Overall effect due to CLA, and linear (L) or quadratic (Q) effects of CLA dose.

Despite CLA infusion, the concentration of cis 9 ,trans 11-18:2 in blood plasma did not increase significantly. Concentration of trans11-18:1 in plasma, however, increased with each increment of CLA infused (Tab. IV). Yields of trans11-18:1 and cis9,trans 11-18:2 in milk fat increased in proportion to CLA dose (Tab. V). Thus, the greatest (3\%) apparent transfer efficency $\left[\left(\mathrm{g} \cdot \mathrm{d}^{-1}\right.\right.$ trans $11-18: 1+\mathrm{g} \cdot \mathrm{d}^{-1}$ cis 9 , trans $11-$ $18: 2$ in milk fat)/g infused cis 9 ,trans 11 18:2] of infused cis 9 ,trans 11-18:2 into milk fat was obtained when $180 \mathrm{~g}$ CLA were infused. Greater availability of exogenous cis9,trans11-18:2 in the rumen may have overcome the capacity for microbes to hydrogenate it completely. Polan et al. [20], first noted that hydrogenation of 18:2n6 to 18:0 in strained rumen fluid decreased linearly as the concentration of 18:2n6 substrate in the incubation increased. Isomers of $18: 1$, however, accumulated up to the point where concentration of $18: 2 \mathrm{n} 6$ in the medium was 3-fold greater than basal. When 18:2n6 concentration was 8-fold greater than basal, hydrogenation was only $12 \%$ [20]. A recent study confirmed that Butirivibrio fibrisolvens A38 produced significant amounts of cis9,trans11-18:2 when the concentration of 18:2n6 was high enough to inhibit hydrogenation of 18:1 isomers to 18:0 [11]. Because trans 11-18:1 could be desaturated to $c i s 9$, trans 11-18:2 in the mammary gland [5], it also could serve as an alternate source for endogenous synthesis of cis9,trans11-18:2. However, the lower ratio of cis9,trans11-18:2 to trans11-18:1 (Tab. VI) in response to $180 \mathrm{~g}$ CLA suggests that desaturation of rumen-derived trans 11-18:1 $\Rightarrow$ cis 9 ,trans 11-18:2 was inhibited, possibly by greater uptake of trans10, cis12-18:2 [5, 12].

Trans12-18:1 and trans13/14-18:1 yields in milk fat increased in proportion to CLA dose. Exogenous cis9,trans 11-18:2 and trans 10 , cis 12-18:2 accounted for $85 \%$ of total CLA isomers infused, and it could be possible that trans12-18:1 and trans 13/ 14-18:1 were derived from the isomerization of end products which accumulated during hydrogenation. Trans-18:1 isomers produced during hydrogenation studies with B. fibrisolvens reflected in part the double bond positions of the substrates. Thus, hydrogenation of 18:2n6 led to production of trans 11-18:1, primarily, but trans9-18:1 also accumulated [8]. However, incubating a 
mixture of cis9,trans 11-18:2 (39\% of total fatty acids), trans 10, cis 12-18:2 (3\%), and cis 8 ,trans 10-18:2 (54\%) resulted in accumulation of trans 8-18:1 (28\% of total fatty acids recovered), trans $9-18: 1$ (7\%), trans 10-18:1 (10\%), trans 11-18:1 (46\%), and trans12-18:1 (9\%) [8]. Isomerization of the cis8- double bond followed by hydrogenation of the trans 10 double bond in cis8,trans 10-18:2 may have led to substantial accumulation of trans8-18:1. In contrast, hydrogenation of the cis 9 double bond in cis 9 ,trans 11-18:2 seemed to be primarily responsible for accumulation of trans 11 18:1. The position of a cis double bond in a CLA molecule could be a factor determining the profile of trans-18:1 isomers produced in the rumen. Although B. fibrisolvens accounts for a large number of total rumen bacteria, numerous isomers also can be produced during hydrogenation of unsaturated fatty acids by other strains of bacteria [7] suggesting microorganisms may possess isomerases other than cis12,trans11-isomerase [9].

Infused CLA was the major source of trans10,cis12-18:2 in blood plasma or milk fat. However, concentrations of trans 1018:1 and trans 10,cis12-18:2 in plasma and yields in milk fat increased in proportion to CLA infused. The greater response in trans10-18:1 (Fig. 2C) resulted from partial hydrogenation of exogenous trans 10 , cis 12-18:2, shown in vitro by Kepler et al. [8], as availability of the CLA in the rumen increased. Similar to cis9, trans11-18:2, however, availability of trans10,cis12-18:2 was large enough to prevent complete hydrogenation (Fig. 2B). The apparent transfer efficiency $\left[\left(\mathrm{g} \cdot \mathrm{d}^{-1}\right.\right.$ trans $10-18: 1+\mathrm{g} \cdot \mathrm{d}^{-1}$ trans 10 ,cis $12-18: 2$ in milk fat)/g infused trans10,cis12-18:2] of infused trans10,cis 12-18:2 into milk fat during the $96 \mathrm{~h}$ period was highest (3\%) when 180 g CLA were infused.

Milk fat percentage and yield decreased significantly when $180 \mathrm{~g}$ CLA were infused relative to basal levels. Yields of saturated 6:0 to $16: 0$ in milk fat also decreased.
Responses were a function of lower concentrations of milk fat or 6:0 to 16:0 fatty acids (Fig. 1A,B), as the concentrations of trans 10 ,cis $12-18: 2$ or trans $10-18: 1$ in milk fat increased (Fig. 2B,C). The overall effect, was a reduction in total fatty acid yields (Tab. V). Lower fat concentration and yields of short and medium-chain fatty acids were previously observed when the concentrations of trans 10-18:1 [6, 19] or trans 10 , cis12-18:2 [2, 12] in milk fat increased. The reduction in milk fat percentage due to trans10-18:1 and trans10,cis12-18:2 was directly proportional to lower fatty acid synthase and acetyl-CoA carboxylase activities in mammary tissue [19]. Based on the level reported to decrease milk fat synthesis [2, 12], however, trans 10,cis12-18:2 appears to be a more potent inhibitor than trans 1018:1. The greater yields of trans 10-18:1 and trans 10 , cis 12-18:2 observed at the $180 \mathrm{~g}$ CLA dose, were proportional to lower milk fat percentage, lower milk fat yield, and reduced yields of short and medium-chain fatty acids

Opposite to the response for mediumchain fatty acids, yield of 18:0 in milk fat increased with each dose of CLA infused. The temporal nature of the increase in 18:0 concentration in milk fat (Fig. 2A) in response to all doses of CLA, suggests hydrogenation of supplemental CLA may have increased availability of 18:0 for desaturation in the mammary gland. Despite greater 18:0 concentration and yield, however, the yield of cis9-18:1 (a product of 18:0 desaturation) was markedly lower (19\% of the reduction in total fatty acid yield) when $180 \mathrm{~g}$ CLA was infused (Tab. V). The lower ratio of cis9-18:1 to 18:0 suggested that desaturation of 18:0 to cis9-18:1 in response to infusion with $180 \mathrm{~g}$ CLA, was impaired. Ratios of fatty acid pairs affected by $\Delta^{9}$ desaturase activity have been previously used to estimate the potential effect of exogenous fatty acids on desaturation. Inhibiting the activity of $\Delta^{9}$ desaturase, by infusing sterculic acid into the abomasum, decreased the ratios of cis $9-14: 1$ to $14: 0$, 
cis9-18:1 to 18:0, or cis9,trans11-18:2 to trans11-18:1 in milk fat [5]. An increase in trans 10 , cis 12-18:2 concentration in milk fat (by infusing the isomer into the abomasum) also decreased the above ratios [2, 12]. In the present study, ratios were lower when CLA was infused at the rate of $180 \mathrm{~g} \cdot \mathrm{d}^{-1}$ (Tab. VI). Overall, results confirmed that greater availability of trans10,cis12-18:2 could decrease lipogenesis and desaturation of long-chain fatty acids in the mammary gland.

\section{CONCLUSIONS}

Trans10,cis12-18:2 was not detected in blood plasma or milk fat unless the CLA mixture was infused, suggesting it is not a major intermediate of 18:2n6 hydrogenation under normal rumen conditions. Trans10-18:1, however, was detected and yield of trans 10-18:1 was proportional to the amount of CLA mixture infused. Thus, under basal conditions in the rumen, trans 10-18:1 may arise primarily from isomerization of cis9-18:1 to trans 10-18:1 (T.C. Jenkins, personal communication) [13] rather than isomerization/hydrogenation of 18:2n6. Due to high susceptibility for hydrogenation, the production of trans 10, cis 12 $18: 2$ in the normal rumen environment must be at least $22 \mathrm{~g} \cdot \mathrm{d}^{-1}$ before it is detectable in blood plasma and milk fat. Furthermore, production must range between 44 and $88 \mathrm{~g} \cdot \mathrm{d}^{-1}$ to potentially reduce de novo synthesis and desaturation in the mammary gland. Overall, results strengthen the view that $18: 1$ or $18: 2$ isomers with a trans 10 double bond may be involved in milk fat depression.

\section{REFERENCES}

[1] AOAC, Official Methods of Analysis, 15th ed. AOAC, Arlington, VA, 1990.

[2] Baumgard L., Corl B., Dwyer D., Saebo A., Bauman D., Identification of the conjugated linoleic acid isomer that inhibits milk fat synthesis, Am. J. Physiol. 278 (2000) R179-R184.
[3] Bickerstaffe R., Noakes D., Annison E., Quantitative aspects of fatty acid biohydrogenation absorption and transfer into milk fat in the lactating goat, with special reference to the cisand trans-isomers of octadecenoate and linoleate, Biochem. J. 130 (1972) 607-617.

[4] Fellner V., Sauer F., Kramer J., Effect of nigericin, monensin, and tetronasin on biohydrogenation in continuous flow-through ruminal fermenters, J. Dairy Sci. 80 (1997) 921-928.

[5] Griinari J., Corl B., Lacy S., Chouinard P., Nurmela K., Bauman D., Conjugated linoleic acid is synthesized endogenously in lactating dairy cows by delta(9)-desaturase, J. Nutr. 130 (2000) 2285-2291.

[6] Griinari J., Dwyer D., McGuire M., Bauman D., Palmquist D., Nurmela K., Trans-octadecenoic acid and milk fat depression in lactating dairy cows, J. Dairy Sci. 81 (1998) 1251-1261.

[7] Kemp P., White R., Lander D., The hydrogenation of unsaturated fatty acids by five bacterial isolates from the sheep rumen, including a new species, J. Gen. Microbiol. 90 (1975) 100-114.

[8] Kepler C., Hirons K., McNeill J., Tove S., Intermediates and products of the biohydrogenation of linoleic acid by Butyrivibrio fibrisolvens, J. Biol. Chem. 241 (1966) 1350-1354.

[9] Kepler C., Tucker W., Tove S., Biohydrogenation of unsaturated fatty acids. IV. Substrate specificity and inhibition of linoleate deltacis12, delta-trans11-isomerase from Butyrivibrio fibrisolvens, J. Biol. Chem. 246 (1970) 2765-2771.

[10] Kepler C., Tove S., Biohydrogenation of unsaturated fatty acids. III. Purification and properties of a linoleate delta-12-cis, delta11-trans-isomerase from Butyrivibrio fibrisolvens, J. Biol. Chem. 242 (1967) 5686-5692.

[11] Kim Y., Liu R., Bond D., Russell J., Effect of linoleic acid concentration on conjugated linoleic acid production by Butyrivibrio fibrisolvens A38, Appl. Environ. Microbiol. 66 (2000) 5226-5230.

[12] Loor J., Alterations in mammary gland synthesis and secretion of fatty acids in response to trans isomers of octadecenoic acid or conjugated linoleic acid isomers, Ph.D. Dissertation, Virginia Tech (2001)

[13] Mortimer C., Niehaus W. Jr., Enzymatic isomerization of oleic acid to trans-10 octadecenoic acid, Biochem. Biophys. Res. Commun. 49 (1972) 1650-1656.

[14] NRC, Nutrient Requirements of Dairy Cattle, 6th rev. ed., Natl. Acad. Sci., Washington, DC, 1989.

[15] Noble R., Moore J., Harfoot C., Observations on the pattern on biohydrogenation of esterified and unesterified linoleic acid in the rumen, Brit. J. Nutr. 31 (1974) 99-108. 
[16] Palmquist D., Santora J., Endogenous synthesis of rumenic acid in rodents and humans, in Yurawecz M.P., Mossoba M.M., Kramer J.K.G. Pariza M.W., Nelson G.J. (Eds.), Advances in Conjugated Linoleic Acid Research, Vol. 1, AOCS Press, Champaign, IL, 1999, pp. 201-214.

[17] Park P., Goins R., In situ preparation of fatty acid methyl esters for analysis of fatty acid composition in foods, J. Food Sci. 59 (1994) 1262-1266.

[18] Parodi P., Conjugated linoleic acid: the early years, in: Yurawecz M.P., Mossoba M.M. Kramer J.K.G., Pariza M.W., Nelson G.J. (Eds.), Advances in Conjugated Linoleic Acid Research, Vol. 1, AOCS Press, Champaign, IL, 1999, pp. 1-11.

[19] Piperova L., Teter B., Bruckental I., Sampugna J., Mills S., Yurawecz M., Fritsche J., Ku K.
Erdman R., Mammary lipogenic enzyme activity, trans fatty acids and conjugated linoleic acids are related in lactating dairy cows fed a milk fat-depressing diet, J. Nutr. 130 (2000) 2568-2574.

[20] Polan C., McNeill J., Tove S., Biohydrogenation of unsaturated fatty acids by rumen bacteria, J. Bacteriol. 88 (1964) 1056-1064.

[21] SAS ${ }^{\circledR}$, Version 8 Edition, SAS Inst., Inc., Cary, NC, 2000.

[22] Stallings C., Kroll G., Kelley J., McGilliard M., A computer ration evaluation program for heifers, dry cows, and lactating cows, J. Dairy Sci. 68 (1985) 1015-1019.

[23] Van Soest P., Robertson J., Lewis B., Methods of dietary fiber, neutral detergent fiber, and nonstarch polysacharides in relation to animal nutrition, J. Dairy Sci. 74 (1991) 3583-3597. 